\title{
Fra afhængighed af USA til indifferens i Latinamerika
}

\section{Jan Gustafsson}

\section{De politiske og økonomiske forudsætninger for interamerikanske relationer er æendret markant. En ny asymmetri truer: USA kan gå hen og blive ir- relevant for flere lande i Latinamerika}

Forholdet mellem USA og Latinamerika var i det foregående århundrede præget af en række asymmetrier: I lange perioder var USA's politiske og økonomiske indflydelse afgørende i store dele af Latinamerika, og USA's rolle som den regionale stormagt blev som hovedregel kun anfægtet af de revolutionære styrer i Cuba og Nicaragua. OAS, Organisationen af Amerikanske Stater, der i anden halvdel af det 20. århundrede var den vestlige hemisfæres vigtigste overnationale organ, var også i høj grad kontrolleret af USA, der brugte den til at fremme egne geopolitiske interesser, særligt under den kolde krig.

Men udviklingen i de seneste par årtier, og særligt tydeligt fra omkring år 2000, har medført en række væsentlige politiske, økonomiske og kulturelle forandringer der gør, at grundlaget for de interamerikanske relationer er ændret ganske væsentligt. Et voksende antal latinamerikanske regeringer accepterer ikke længere, at USA skal have en dominerende rolle i regionen, og for en stor del af landene i Sydamerika er USA ikke længere så vigtig en strategisk partner som tilfældet var for et par årtier siden. Fra USA's side synes der at være en vis træghed med at forstå disse nye betingelser. Man har svært ved at fralægge sig stormagtsvanerne og resultatet kan blive, at stadig flere latinamerikanske nationer vender sig mod andre partnere, så USA i yderste konsekvens kan ende med at blive isoleret i den region, der engang var landets helt egen boldgade. Endnu er det ikke nået dertil, men de to seneste præsidenter i Washington har ikke formået at leve op til deres latinamerikanske 
kollegers forventninger, og det gælder måske i særlig grad Barack Obama. Samtidig skal det siges, at der var store forventninger til, at netop Obama ville være den præsident, der formåede at skabe en ny stil i regionens relationer.

I det følgende vil jeg forsøge at komme nærmere ind på forholdet mellem USA og Latinamerika siden omkring år 2000 samt på nogle af de forandringer, der har ændret på forudsætningerne for de hemisfæriske relationer i samme periode. Diskussionen vil tage udgangspunkt i Obamas magtovertagelse for ca. fire år siden, og derefter vil jeg se på udviklingen både før og efter dette tidspunkt.

\section{Håbet med Obama}

\section{Da Barack Obama overtog præsi-} dentposten i USA, mente mange, at der nu åbnedes muligheder for en ny og mere positiv æra i de interamerikanske relationer. Hvor USA's forrige regering havde haft flere fiaskoer end succeser i regionen, gav Obamas diskurs om forandring sammen med hans åbne og pragmatiske stil næring til håb om, at USA ikke længere ville spille rollen som regional supermagt og faderfigur. Og da Obama i april 2009 mødtes med sine latinamerikanske kolleger til sit første interamerikanske topmøde, der fandt sted i Port of Spain (Trinidad og Tobago), vil de fleste mene, at han klarede sig ganske godt, selv om mødet ikke førte til grundlæggende ændringer i relationerne mellem USA og Latinamerika.

Latinamerikanerne mødte en åben og positiv præsident fra USA, der i hvert fald på det retoriske og symbolske plan viste et ønske om at 'modernisere' relationerne mellem landene i den vestlige hemisfære.

Der var venlighed, håndtryk og positive vibrationer, ikke blot til de svorne konservative allierede i regionen, men også til venstreorienterede ledere som Hugo Chávez (Venezuela) og Ero Morales (Bolivia). Og den positive stil så ud til at være gensidig. Der var smil og en belærende (og måske let ironisk) boggave fra Chávez og mange positive tilkendegivelser over for den mere eller mindre direkte formulerede intention om en ny stil i amerikansk udenrigspolitik. Perspektiverne for en positiv udvikling i de interamerikanske relationer syntes således at være gode $\mathrm{i}$ starten af Obamas præsidentperiode.

Men siden har der været flere skuffelser end glæder. Selv om der er grund til at mene, at de hemisfæriske relationer i dag på mange måder er bedre end under den foregående administration i USA, er forventningerne til dels afløst af skepsis og tendenser til skuffelse. Den første store skuffelse kom allerede et par måneder efter topmødet, da Honduras' præsident, Manuel Zelaya, blev væltet ved et kup. Både hans egne partifæller og den øvrige del af den politiske og økonomiske elite 
var stærkt utilfredse med Zelayas ønske om at nærme sig Venezuela og andre af regionens venstreorienterede administrationer gennem tilslutning til organisationen ALBA for $ø$ konomisk integration, ligesom præsidentens ønske om at ændre på grundloven ved en folkeafstemning blev anset for antikonstitutionel.

Kuppet og den efterfølgende de facto regering under Roberto Micheletti blev stærkt fordømt i hele Latinamerika, mens USA's reaktioner var mere lunkne. Washington var heller ikke villig til at følge op på fordømmelsen med mere konkrete tiltag. Specielt var udenrigsminister Hillary Clinton meget uvillig til at gå ind på de latinamerikanske forslag om sanktioner med de facto-regeringen i Tegucigalpa.

USA's attitude gav mange latinamerikanere mindelser om tidligere tiders ambivalente holdning til demokrati; i første række kom USA's interesser og i anden række demokrati og menneskerettigheder i de enkelte latinamerikanske nationer. Et eksempel på en sådan holdning havde man set så sent som i 2002, da Bush-administrationen gav støtte til det kortvarige kup mod præsident Chávez i Venezuela.

\section{USA svært ved dialog}

Obamas holdning var en forbedring i forhold til USA's reaktion på kuppet i Venezuela i 2002, men den var stadig utilstrækkelig.
Der synes heller ikke at være sket større forbedringer i forhold til en række andre bi- og multilaterale problemstillinger mellem USA og Latinamerika. Det gælder for eksempel produktion og smugling af narkotika, kriminalitet og sikkerhed samt migration. Ikke blot er disse problemer langt fra løst, men det er som om USA har svært ved at indgå i en dialog, hvor de latinamerikanske præmisser tages seriøst.

Hvor USA især fokuserer på afbrænding af cocaplantager i Bolivia og Colombia, kræver latinamerikanerne en seriøs indsats over for det enorme marked for illegal narko i USA. Ligeledes opfattes USA's militarisering af narkokonflikten og oprettelsen af amerikanske baser i Colombia (i 2009) som en potentiel trussel mod de latinamerikanske landes suverænitet. Hvor USA ser narkokrigen i Mexico som et mexicansk problem, insisterer Mexico på, at hovedparten af de våben, banderne bruger, købes i USA og smugles ind i Mexico. Og hvor USA i stadig højere grad forsøger at lukke grænsen mod Mexico - der også er grænsen mod Latinamerika - ønsker latinamerikanerne en dialog om hele migrationsproblematikken.

Et andet eksempel er Cuba. Obamas politik over for Cuba har været præget af en vis vaklen. Der har været åbninger for rejser og pengeoverførsler til Cuba - først og fremmest til fordel for cubanere bosat $\mathrm{i}$ USA - men også tendenser til tilba- 
geskridt, og frem for alt har USA's politik været præget af en manglende evne til at drage fordel af magtskiftet fra Fidel til Raúl Castro - næsten sammenfaldende med Obamas egen magtovertagelse, der betød overgangen til en mere pragmatisk politik i Havanna. Obama har ikke formået at vende den negative dynamik i forholdet mellem de to lande.

Problemet er ikke kun af bilateral karakter. For et flertal af latinamerikanerne er USA's politik over for Cuba et udtryk for manglende accept af de latinamerikanske nationers suverænitet og ikke et spørgsmål om demokrati eller diktatur i Cuba, sådan som det ses fra USA's side. Obamas administration har således ikke formået at løse det grundlæggende problem, som forholdet mellem USA og Cuba udgør for de interamerikanske relationer som helhed.

\section{Topmøde i Cartagena}

Dette blev synligt igen ved næste topmøde, der blev afholdt i år i Cartagena i Colombia. Her blev et beslutningsforslag om at invitere Cuba til det næste topmøde i Panama i 2015 blokeret af USA og Canada, der som eneste land stemte imod. Inden da havde Colombias centrumhøjre præsident, Juan Manuel Santos, været i Havanna for at bede cubanerne om ikke at få deres venner i regionen til at boykotte mødet på grund af Cubas udelukkelse. Den pragmatiske Raúl Castro beroligede Santos, der kunne rejse hjem igen og organisere topmødet.

Der var heller ikke de store fremskridt at spore i samarbejdet mellem USA og Latinamerika om de store problemer i regionen. USA var ikke indstillet på overhovedet at diskutere en legaliseringsstrategi som en del af løsningen på narkokrigen, sådan som nogle latinamerikanske lande foreslog. Man var heller ikke åben over for kritikken af USA's monetære politik, der af Brasiliens præsident, Dilma Rousseff, blev anset som ensidig og til skade for regionen.

Derudover stemte alle deltagere, igen med undtagelse af USA (der undlod) og Canada (der stemte imod), for en resolution, der støttede Argentinas krav om forhandlinger med Storbritannien om suveræniteten over øgruppen Malvinerne (Falklandsøerne) i Sydatlanten.

I det hele taget fremstod grænsen mellem USA og Canada på den ene side og Latinamerika på den anden synligere end på noget tidligere topmøde.

At medierne endte med at fokusere væsentligt mere på skandalen omkring nogle amerikanske sikkerhedsfolks brug af lokale prostituerede end på topmødets indhold, fik måske opmærksomheden lidt væk fra Obama-administrationens relative fiasko i regionen, men det bidrog måske også til at cementere en idé om arrogante og respektløse 'gringoer' 
blandt latinamerikanerne. Topmødet i Cartagena viste igen, at Obamas administration har haft svært ved at leve op til forventningerne om en ny stil i de interamerikanske relationer.

\section{Fndrede prioriteter}

Samtidig skal det understreges, at Obama overtog et sæt relationer til Latinamerika, der på mange måder var blevet forværret under den foregående præsident, George W. Bush. Bush havde godt nok indledt sin første præsidentperiode i starten af 2001 med fokus på Latinamerika, som blev opfattet som en første prioritet i de internationale relationer.

Mexico i særdeleshed og regionen i sin helhed var i en periode genstand for USA's interesser og en del initiativer, men disse prioriteter blev ændret brat, da Bush-administrationen indledte sin 'krig mod terror'. Med den kom en ny periode af manikæisk tankegang i USA's udenrigspolitik: der er de gode, som er med os, og de onde, som er imod os.

Latinamerikanerne havde vanskeligt ved at se sig selv i dette billede. Man tenderede mod at sympatisere med USA i forlængelse af 11. september 2001, og regeringen i Havanna var endog blandt de første til at tilbyde humanitær hjælp til New York (et tilbud, der dog ikke blev accepteret).

Men et flertal af latinamerikanerne opfattede ikke 'krigen mod ter- ror' som deres anliggende. Man havde intet udestående med Mellemøsten eller de muslimske lande, og Latinamerikas egne terrorproblemer sås som et begrænset og lokalt problem, relateret til for eksempel guerillagruppen Den Lysende Sti i Peru.

Derfor kom det bag på såvel regeringer som den almene opinion $\mathrm{i}$ det meste af Latinamerika, at Bushadministrationen på et tidspunkt inkluderede Cuba i 'Ondskabens Akse' af terrorpromoverende nationer. Og da Otto Reich (trods navnet af cubansk oprindelse), USA's daværende hovedrådgiver for forholdet til Latinamerika, fik inkluderet Venezuelas venstreorienterede præsident, Hugo Chávez, i en særlig udgave af 'ondskabens akse', vakte det ligeledes irritation.

De problemer denne holdning bidrog til at skabe, var ikke så meget i forhold til Havanna og Caracas, hvor man blot fik bekræftet USA's fjendtlighed og 'imperialistiske' holdning.

Men i den øvrige del af regionen - uanset hvordan man ellers så på præsidenterne Castro og Chávez vakte denne holdning både undren og irritation, og frem for alt fik man endnu en gang bekræftet at faderfiguren, USA, endnu ikke var moden nok til at acceptere, hvad stort set alle latinamerikanske regeringer krævede i det 21. århundrede, nemlig bilaterale og multilaterale betingelser på lige fod. 
Og denne symmetri handlede ikke kun om økonomi og diplomati, men også om international politik på det symbolske og retoriske niveau. Det var således en væsentlig fejl fra Bush-administrationens side at tro, at man uden videre kunne inkludere Latinamerika i sit nye verdensbillede med 'gode' og 'onde' stater, med allierede og ikke-allierede og med relevante og irrelevante stater.

Herudover begyndte der også at opstå problemer for USA's generelle politiske og økonomiske strategi for regionen, der siden 1990'erne havde bestået i at skabe en generel frihandelszone, det såkaldte Free Trade Area of the Americas (FTAA, eller ALCA i spansksproget forkortelse).

\section{Venstrebølgen}

For det første var der en voksende opposition mod den neoliberale strategi og politik, der lå bag tanken om FTAA. For det andet var flere latinamerikanske regeringer og forhandlere utilfredse med, hvad man anså for endnu et symptom på asymmetrien i relationerne mellem Nord og Syd: de latinamerikanske økonomier forventedes at være helt åbne $o g$ fri for al form for protektionisme, mens USA stadig forbeholdt sig retten til at yde støtte til landbruget og andre for landet centrale sektorer.

På den baggrund var det ikke mærkeligt, om end lidt af et chok for USA, at FTAA faldt til jorden ved topmødet i Mar del Plata, Argentina, i november 2005. Hovedparten af de sydamerikanske lande var imod, mens Mexico i nord og de fleste mellemamerikanske lande var for. Hugo Chávez morede sig med sine retoriske jokes mod USA, og han opstillede organisationen ALBA som modstykke til FTAA/ALCA.

Men afgørende var nok især Brasiliens og værtslandet Argentinas modstand mod projektet. Godt nok er der både før og efter 2005 blevet undertegnet bilaterale frihandelsaftaler mellem USA og latinamerikanske lande, men det store projekt er indtil videre skrinlagt, og det var nok en af Bush-administrationens største fiaskoer i forholdet til Latinamerika.

Men denne meget synlige fiasko var ikke alene et problem i sig selv, men også et symptom på en række nye politiske, økonomiske og kulturelle tendenser, som Bush-administrationens tidlige og meget konservative rådgivere på Latinamerikaområdet ikke for alvor havde øje for.

Politisk har perioden fra 19992009 i Latinamerika været præget af den såkaldte venstrebølge, der blandt andet har betydet, at det meste af Sydamerika omkring 2006-8, med undtagelse af Colombia og Peru, var regeret af venstre- eller centrumvenstreadministrationer, der næsten alle har været aktive fortalere for en ny type interamerikan- 
ske relationer, hvor det ikke er USA alene, der sætter dagsordenen.

Der skal ses nuanceret på denne venstrebølge - i nogle tilfælde drejer det sig om regeringer på linje med de vesteuropæiske socialdemokratier, mens der i andre er tale om radikale regeringer baseret på nye sociale bevægelser - men et fælles træk har været en stigende konsensus omkring tanken om en 'ny uafhængighed', hvor man ikke længere accepterer asymmetriske internationale relationer.

$\varnothing$ konomisk har det foregående årti også bragt væsentlige forandringer for Latinamerika, frem for alt med Kinas voksende betydning som samhandelspartner, i væsentligt omfang på bekostning af USA. Ud over Kina har også lande som Rusland, Indien og Iran øget deres engagement i regionen. En del af landene, med Brasilien som spydspids, har også valgt at lægge en stor indsats $\mathrm{i}$ en Syd-Syd strategi, hvor det ikke blot handler om samarbejde de latinamerikanske lande imellem, men også om et bredere, strategisk samarbejde med lande i Asien og Afrika.

Selv om USA fortsat er blandt de vigtigste $\varnothing$ konomiske og handelsmæssige partnere for en del latinamerikanske lande, betyder Kinas, Indiens og andre landes voksende rolle, at denne situation er under hurtig forandring samtidig med, at det øgede pres efter råvarer stiller en del af regionens økonomier i en positiv situation med stigende priser og nem afsætning på centrale eksportvarer.

Alt i alt er både de politiske og $\varnothing$ konomiske forudsætninger for de hemisfæriske relationer således ændret grundlæggende i det første årti af dette århundrede. Disse nye forudsætninger sammen med en række latinamerikanske landes nye strategier inden for handel, politik og internationale relationer kunne pege på muligheden - eller faren, om man vil - for en ny asymmetri: USA kunne gå hen og blive irrelevant for i hvert fald en del af Latinamerika.

Denne fare har Obama-administrationen ikke formået at bremse, tværtimod. Selv om der ikke er tvivl om, at dens indsats over for Latinamerika har været mere succesfuld end den foregående regerings.

Man har som sagt gjort en indsats for at nærme sig de latinamerikanske nationer på mere ligeværdige betingelser, og på især bilateralt plan har der været positiv udvikling i forholdet mellem USA og flere latinamerikanske lande. Men USA har ikke formået at tage dette skridt fuldt ud, hverken i sin retorik eller politiske praksis, og man har kun i begrænset omfang formået at møde de latinamerikanske nationer i løsningen af de store problemer, som plager regionen eller dele af den.

\section{Kulturel enhed}

Samtidig står det klart, at Latinamerika og Caribien i stadigt højere 
grad ser sig som en kulturel og regional enhed, hvor USA (og Canada) ikke har en plads. Oprettelsen af Unionen af Sydamerikanske Nationer, UNASUR, i 2008, med ratificering af et flertal af medlemslande i 2011 er ét udtryk for denne udvikling.

Fællesskabet af Latinamerikanske og Caribiske Stater - CLAC eller CELAC i henholdsvis engelsk eller spansk/portugisisk/fransk forkortelse - er endnu et, og nok vigtigere endnu. CELAC omfatter 33 suveræne amerikanske stater, og kun USA og Canada er ikke med. Endnu spiller både UNASUR og CELAC en mere symbolsk end praktisk politisk og økonomisk rolle, men den kan komme, og frem for alt kan de to organisationer ses som varsler om, at Latinamerika ser sin fremtid i fællesskaber med ligesindede stater, som på forhånd respekterer regionens og dens nationers absolutte suverænitet.

For USA kan det på længere sigt betyde, at man mister terræn i Latin- amerika, og dermed også muligheden for at styrke sin egen økonomi gennem et godt forhold til Latinamerika, der som helhed indtil videre har klaret sig væsentligt bedre gennem recession og krise end USA.

USA's genvalgte præsident vil stå med de samme udfordringer i forhold til Latinamerika som Bush gjorde og Obama i sin første periode. Og der er ikke umiddelbart noget der tyder på, at USA ændrer sin nuværende strategi. USA vil satse på et godt bilateralt forhold til de latinamerikanske lande, man allerede ser som sine allierede, men forholdet til resten af regionen kan blive præget af en voksende, gensidig indifferens.

Jan Gustafsson er lektor ved Københavns Universitet, Institut for engelsk, germansk og romansk med speciale $i$ Latinamerika. Tidligere ansat ved bl.a. Copenhagen Business School, her leder af Center for the Study of the Americas 2010-12. Kommenterer jaunligt latinamerikanske forhold i danske medier. 